eISSN: 2503-4197, pISSN: 2527-5070 www. indonesian-efl-journal.org

\title{
A Phonological Analysis of English Loanwords in Spanish Language using Distinctive Features
}

\author{
Ana Puspitasari \\ Diponegoro University, Indonesia \\ e-mail: ana.puspitasari@gmail.com \\ Agus Subiyanto \\ Diponegoro University, Indonesia \\ e-mail: subaling@gmail.com
}

\begin{abstract}
:
Loanwords occur as the result of language contacts within the community. In Spanish language, there are borrowing words existing as the effect of the contact with English language. This research aimed at finding out the phonological process in Spanish vocabulary which were absorbed or borrowed from English language. Distinctive features were used as the approach. The research conducted was qualitative descriptive. It used 30 Spanish vocabulary borrowed from English language as the object. At the end of this research, it was found out that the phonological process which happened, involved substitution processes; not only in the consonant phonemes but also in vowel phonemes.
\end{abstract}

Keywords: distinctive features, loanwords, Spanish phonology

\section{INTRODUCTION}

Language contacts occur in numerous languages in the world. Thomason (2001) states that "there is no evidence that any languages have developed in total isolation from other languages". This means that there is always a contact or relation between one language and another. Said by Nykopp (2017) that language contacts might be strong 
(intense) or weak. This depends on the number of language variation used in a particular area. Loanwords are one form of a language contact, as stated by Aikhenvald that "Contact-induced changes may be system-altering or system-preserving ... either by restructuring the grammatical system or borrowing a term into an existing system." (2006). It is always interesting to find out the process of how a loanword gets an influence from other languages. This becomes the reason why this study is conducted. As the limitation of the study, this research focuses on the phonological processes which occur in the English loanwords in Spanish language.

There have been some studies concerning distinctive features used in the studies of generative phonology. Some studies focused in phonological processes in foreign languages. Nafisah (2017) has studied the phonological processes of a number of languages using an approach of generative phonology. Using Indonesian language, Javanese language, Arabic language, and Zoque language she finds out that generative phonology is able to be used to explain the phonological processes, such as sound addition, sound deletions, coalitions, and assimilations. Meanwhile, Anam (2017) examines the phonological process of $i k h f a$ in Arabic language using the approach of generative phonology. He, later, finds out that there are consonant assimilation and vocalic nasalisation existing in the duality of phonological process.

Some studies of foreign language focusing on loanwords have been conducted by Aprillianti (2019), Zen (2016), and Muslihah (2018). Aprillianti (2019) explores Javanese words borrowed from foreign languages using distinctive features. In her conclusion, it is found out that there are three sound changes of vowel sounds and four phonological rules, four sound change and four phonological rules of consonant sound. The sound change is affected by differences of phonological system between Javanese and foreign languages. Zen (2016) investigates the phonological changes of loanwords in Sansekerta language into Javanese language using distinctive features analysis. The study results in the facts that there are changes in sound segments, sound insertions, sound deletions, sound fusions, and sound transpositions. Muslihah (2018) wrote about the phonological process and phonological rules in loanwords of English language into Japanese language through generative phonological studies. The data from a Japanese dictionary of loanwords were then analysed and described using generative phonology rules and distinctive features. The study resulted that phonological process of loanwords in English language into Japanese is based on the internal differences in the phonology system in both English and Japanese language.

Vernacular languages also become an interesting subject for generative phonology studies. Two studies about assimilation process were conducted by Aulia and Nurhayati (2020) and Jaya (2019). Aulia and Nurhayati (2020) use sound receiving and sound dissolution as the focus of the study. They highlight the location of sound receiving at the vocal end of a stem with a possessive property and sound dissolution at the beginning, middle, and end of a sound. Arifiani and Subiyanto (2019) describe syllables and vocal neutralization's structure in the formation of verbs of Bayan dialect in Sasak language using Schane's theory of generative phonology. The study shows 
that the sounds nearby may cause other sounds which have the closest features. Meanwhile, Javanese language has been in interesting subject to explore. Reynaldi (2017) compares the differences between standard Mataraman and Banyumas dialect of Javanese language using phonological rules and distinctive features. Later, he finds out that there are sound changes in those two dialects, that is, $/ \mathrm{o} / \mathrm{into} / \mathrm{a} /$ and there is deletion process in the final position of the stem. Banyumas dialect also becomes the focus of a study done by Huda and Subiyanto (2017). Their study aims at describing the phonological process in verbal nasalization of Banyumas dialect. At the end, they find out that there are two most frequent phonological processes. Those processes are assimilation and syllable-structure process. Erawati (2017) studies the interpretation of sound segments and frequency differences in Old Javanese language using distinctive feature theory and speech analyser mechanic method. At the end, it is concluded that the vocal sound segments in Old Javanese language has interplay of sound segments and classes. Another study about Javanese language is executed by Hakim (2016). He discusses the phonological variations of Brebes (Brebean) dialect of Javanese language. The result of the study shows that there are phonological variations in the dialect, such as assimilation, neutralization, and syllable-structure adding.

From those studies mentioned, all of them use distinctive features as the tool for investigation, which is similar to this study. There are two studies focus on loanwords from foreign languages, as well. Yet, there is not any study which investigates the phonological process of English loanwords in Spanish language. That is why this study is different from studies previously conducted. By using the theory of Distinctive Features, this study is conducted to answer a research question of how phonological processes happen in the English loanwords in Spanish language.

\section{LITERATURE REVIEW}

\subsection{Loanwords}

A loanword is defined in the Longman Dictionary of Contemporary English as 'a word taken into one language from another' (2014). English words which are taken and absorbed into Spanish language comes from the process of Anglicims. According to Dictionary of the Spanish Royal Academy, Anglicism is defined as "Word of the English language used in another one". Cited from Bojčić and Plavša (2012), if anglicism is united into the system of a language, it becomes a loanword and needs to be espoused to the receiving language. Many English words are adopted in Spanish language for some reasons. First, it is because of the high frequency of use of English in many countries worldwide, including Spain. This makes people are more familiar with English language. Simultaneously, the use of English language or words increase. Second, a frequent use of technology, especially among young adults, makes English language penetrate more easily in Spain. English is easily spread using televisions, internet, and social media. 


\subsection{Phonological System of English Language}

English language is known as the global language among speakers of many languages in the world (Rao, 2019). It is the third mother language mostly spoken in the world after Mandarin and Spanish language.

Segmental sounds in English are classified into consonants and vowels. Consonants are sounds which involve one or more constriction in the vocal tract (Hayes, 2011). Consonants are divided into three categories based on the voicing state, place of articulation, and manner of articulation. Summarized from Hayes (2011), the voicing state refers to the activities of the vocal folds. If the vocal folds do not vibrate, the consonants are called voiceless. Meanwhile, when the folds vibrate, the consonants are said to be voiced. The sounds [p] and [b] are both produced in the same place in the mouth. Yet the first is voiceless because [p] is produced with no vibration of the vocal tract, while the latter is voiced since it is produced by vibrating the vocal tract.

The place of articulation refers to the description of area or place of the resonating cavities where the obstacle in the vocal tract occurs. In English, places of articulation are bilabial, labio-dental, dental, alveolar, post alveolar, palatal, velar, and glottal. Bilabial sounds are produced as the upper and lower lips articulate together. English has a voiceless bilabial stop [p], a voiced bilabial stop [b], and a voiced bilabial nasal [m]. Labiodental sounds are sounds that are made produced by touching the lower lip

and the upper teeth. There are a voiceless labiodental fricative [f] and a voiced labiodental fricative [v] in English. Dental sounds are produced as the tongue touches the upper teeth. Alveolar sounds are made when the tip of the tongue touches an area just in front of the alveolar ridge. There are a voiceless alveolar stop [t], a voiced alveolar stop [d], voiceless and voiced alveolar fricatives [s z], a voiced alveolar nasal [n], a voiced alveolar lateral approximant [1], and a voiced central approximant [x]. Post-alveolar sounds are produced when the blade of the tongue touches an area just behind the alveolar ridge. Palatal sounds are produced when the tongue blade and the front part of the tongue body touches the hard palate. The example of palatal sound [palatal approximant] is [j]. Velar sounds are made as the tongue body touches the hard or soft palate. There are three velar sounds in English, that are, a voiceless velar stop [k], a voiced velar stop [g], and a velar nasal [y]. The last one, glottal sounds, are produced when the vocal cords move close to another. There is one glottal sound in English, that is, a voiceless glottal fricative [h].

The manner of articulation means the way the configuration and interaction of the speech organs when producing speech sounds. English has plosives, nasals, fricatives, and approximants. Plosives are produced with a complete closure in the oral tract as the velum raises, that prevents air to escape through the nose. In English, plosives are sounds [ $\mathrm{p} \mathrm{t} \mathrm{k} \mathrm{b} \mathrm{d} \mathrm{g].} \mathrm{Nasals} \mathrm{are} \mathrm{produced} \mathrm{as} \mathrm{there} \mathrm{is} \mathrm{a} \mathrm{complete} \mathrm{closure} \mathrm{of} \mathrm{the} \mathrm{oral} \mathrm{tract}$ with lowering the velum to make the air escape through the nose. There are three nasal sounds in English, that are, [m n y]. Meanwhile, fricatives happen as the mouth is positioned to block the air passage without a complete closure which makes friction noise. In English, fricatives include [f $\mathrm{v} \theta$ б $\mathrm{s} \mathrm{z} \int 3$ ]. Approximants are consonant 
sounds which are made as two articulators are close together without touching each other. Approximants in English include [j w 1 r].

Cited from McMahon (2002), in English, vocal phonemes may be long (/i:/, /u:/, /3:/,

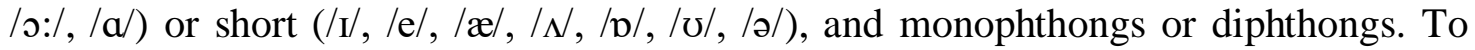
describe vowels more proportionally, there are three parameters to consider: height, front-ness, and rounding. Referring to the height of the tongue, vowels can be high, mid, or low. According to the front-ness of the tongue, vowels are categorized into front, central, or back. And, based on the rounding of the lips, vowels can be classified into rounded and unrounded.

\subsection{Phonological System of Spanish Language}

Phonological system of Spanish language is significantly different from the one in English languages. This can be seen from the vowel sounds and the stress in the speech. This distinction causes a difficulty for Spanish natives to obtain English accents resembling the native speakers of English language. Coe (1987) added that "European Spanish speakers, in particular, probably find English pronunciation harder than speakers of any other European language.".

Spanish language has a phonological system which has developed since the $12^{\text {th }}$ Century (Lloyd, 1989). In most Spanish dialect, there are 5 pure vowels and 18 consonants.

Quoted from Salcedo (2010), vowels are described using parameters, i.e. height of the tongue (high, mid, and low) and position of the tongue (front, central, and back). The five vowels are high front [i], mid front [e], low central [a], mid back [o], and high back $[\mathrm{u}]$.

Mackenzie (1999-2020) explains that Spanish consonants are produced with a partial or a complete block of the airstream in the oral tract. Resembling English language, there are three factors determining the nature of the consonants are the place of articulation, the manner of articulation, and whether the sound is voiced or voiceless. Thus, the Spanish consonants are bilabial stops [p b], bilabial fricatives $[\beta]$, bilabial nasals [m], labiodental fricative [f], labiodental nasals [m], dental stops [t d], dental fricatives $\left[\begin{array}{ll}\theta & \text { d}\end{array}\right]$, dental nasals [n], alveolar fricatives [s z], alveolar approximants [ $\mathrm{x}$, alveolar nasals [n], alveolar laterals [1 l], alveolar tap [r], alveolar trill [r], post-alveolar affricate $\left[\mathrm{t} \int \mathrm{d} 3\right]$, palatal fricatives [j], palatal nasals $[\mathrm{n}]$, palatal laterals $[K]$, velar stops $[\mathrm{kg}]$, and velar fricatives $[\mathrm{x} \mathrm{\gamma}]$.

\subsection{Transformational Generative Phonology}

Transformational Generative Phonology (Generative Phonology) is one of components of transformational generative grammar which was adopted and refined as the one of Semantic generative and Syntactic Generative grammar (Simanjuntak, 1990). It was Chomsky who first introduced this approach in his book 'Syntactic Structure'. As said by Simanjuntak (1990), one of the most essential features of generative phonology is its nature of analysis, which is morphophonemic of the sound changes. It is from the 
sound changes that a rule or formula can be drawn. Schane (1992) explains that a rule is the prominent feature of generative phonology. There are four phonological rules in generative phonology, as stated in his book 'Generative Phonology', as follows.

Assimilation, where segments become more alike; syllable structure, where there is alteration in the distribution of consonants and vowels; weakening and strengthening, where segments are modified according to their position in the word; and neutralization, where segments merge in a particular environment. (Schane, 1992)

\subsection{Distinctive Features}

Distinctive features are distinguished features owned by a unit which make it different from other units of the same type. This concept works for all properties in the world, including sound of a language (Simanjuntak, 1990). Also noted by Simanjuntak (1990), distinctive features are defined as attributes preserved by a phoneme which distinguishes it from other phonemes. He also underlines that distinctive features are the attributes of the smallest unit or phoneme which are used to differentiate meanings. Hall (2001) remarks that distinctive features are capable of solving phonological phenomena in a language. In distinctive features there are three major groups as Schane (1992) illustrates. They are major class features, manner features, and place features. Major class features cover $[+]$ syllabic, $[+]$ consonantal, and $[+]$ sonorant. The first two major class features are used to distinguish consonants, vowels, and approximants, whereas the [+] sonorant feature is used to differentiate obstruent and non-obstruent consonants. Another group of features is manner features which comprise [+] continuant, $[+]$ delayed release, $[+]$ nasal, and $[+]$ lateral. The last group, the place features covers $[+]$ coronal, $[+]$ anterior, $[+]$ strident, and $[+]$ distributed.

\section{RESEARCH METHODOLOGY}

\subsection{Data and Source of Data}

The subject of this study is English loanwords in Spanish language and their corresponding English words. Meanwhile, the object of the study is the phonological processes within words in those two languages.

The English loanwords in Spanish are taken from the book Must-Know Spanish, which was written by Gilda Nissenberg (2010). This thematic vocabulary book contains 4000 Spanish terms which are divided into 12 sections. There are 30 loanwords used for this study and they come from the domain of technology, sport, food and beverages, and things related to everyday life.

\subsection{Data Collection Technique}

Simak method is used for providing the data in this study. According to Sudaryanto (2015), Simak method is defined as a method of collecting data by scrutinizing the language being used. In particular, Simak Bebas Libat Cakap technique is used in this study. As Sudaryanto (2015) illustrates, that technique means that researchers do not 
participate in the data making. Instead, they merely act as reviewers for written data which are already available.

In finding the phonetic transcriptions for each data, some sources are used. A website Spanish Learning Made Easy at http://spanishdict.com/ is used for checking transcriptions for English loanwords in Spanish language. Meanwhile, online Longman Dictionary of Contemporary English at http://ldoceonline.com/ is used for examining phonetic transcriptions of the English words. International Phonetic Alphabet (IPA) phonetic transcriptions are used in this study and they are provided by those two sources.

\subsection{Data Analysis Procedures}

For analysing the data, there are a number of procedures to follow. First, identifying English loanwords in Spanish language from the book Must-Know Spanish and finding the English words borrowed for each Spanish word. Second, identifying the phonetic transcription of each data found. For data of Spanish words, the IPA phonetic forms are obtained from http://spanishdict.com/, while for data of English words, the IPA phonetic transcriptions are obtained from http://ldoceonline.com/. Next, conducting analyses for each data using distinctive features. Last, drawing conclusions based on the preceding analyses.

\section{FINDINGS}

From the identification of the Spanish words in the data source, below are English loanwords in Spanish language along with their phonetic transcriptions.

Table 1. English loanwords in Spanish language

\begin{tabular}{|c|c|c|}
\hline No & English & Spanish \\
\hline 1 & bacon [beI-kın] & béicon [bei-kon] \\
\hline 2 & baseball [beIs-bal] & beisbol [beis- $\beta$ ol] \\
\hline 3 & basketball [bæs-kit-bal] & básquetbol [bas-ket- $\beta o l]$ \\
\hline 4 & bowl [boul] & bol [bol] \\
\hline 5 & boycott [bor-kat] & boicot [bo-i-kot] \\
\hline 6 & camping [kæmp-In] & camping [kam-pin] \\
\hline 7 & chat $\left[\mathrm{t} \int \mathrm{t}\right]$ & chat $[\mathrm{t}$ at $]$ \\
\hline 8 & click [klık] & clic $[\mathrm{klik}]$ \\
\hline 9 & cocktail [kak-terl] & cóctel [kok-tel] \\
\hline 10 & comic $[\mathrm{ka}-\mathrm{mIk}]$ & comic [ko-mik] \\
\hline 11 & football [fotbs:] & fútbol [fut-bol] \\
\hline 12 & gangster [gein-stər] & gangster [gans-ter] \\
\hline 13 & goal [govl] & gol [gol] \\
\hline 14 & golf [galf] & golf [golf] \\
\hline 15 & hockey [ha-ki] & 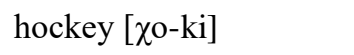 \\
\hline 16 & leader $[1 \mathrm{i}-\mathrm{d}\lrcorner \mathrm{x}]$ & líder [li-ðer] \\
\hline 17 & meeting [mi-rıy] & mitin [mi-tin] \\
\hline
\end{tabular}

Indonesian Journal of EFL and Linguistics, 5(2), 2020 
Ana Puspitasari \& Agus Subiyanto

\begin{tabular}{lll}
18 & nylon [nailpn] & nailon [nai-lon] \\
19 & outlet [aot-lit] & outlet [aut-let] \\
20 & pamphlet [pæm-flit] & panfleto [pam-fle-to] \\
21 & panty [pænti] & panti [pan-ti] \\
22 & parking [pa-kın] & parking [par-kin] \\
23 & picnic [prk-nik] & picnic [pik-nik] \\
24 & post [poust] & post [post] \\
25 & sandwich [sænd-witf] & sanduche [san-witf] \\
26 & smoking [smərkın] & esmoquin [es-mo-kin] \\
27 & snob [snab] & esnob [es-noß] \\
28 & surf [sə.f] & surf [surf] \\
29 & taxi [tæk-si] & taxi [tak-si] \\
30 & tennis [tenis] & tenis [te-nis] \\
\hline
\end{tabular}

The phonological processes found in the English loanwords in Spanish language comprise substitutions, with details as follow.

\subsection{Substitution of Phoneme / $/ \mathbf{y} /$ into /n/}

Phoneme / $\mathrm{y} /$ all word positions in English changes into /n/ in Spanish. The sound of velar nasals of the English is deleted and turns into alveolar nasals in Spanish.

Table 2. Substitution of phoneme $/ \mathrm{n} /$ into $/ \mathrm{n} /$

\begin{tabular}{cll} 
No & \multicolumn{1}{c}{ English } & \multicolumn{1}{c}{ Spanish } \\
\hline 1 & camping [kæmp-In] & camping [kam-pin] \\
2 & gangster [gern-stər] & gangster [gans-ter] \\
3 & meeting [mi-rı]] & mitin [mi-tin] \\
4 & parking [pa-kın] & parking [par-kin] \\
5 & smoking [smərkın] & esmoquin [es-mo-kin]
\end{tabular}

Below is the phonological rule.

$$
\begin{array}{rll}
/ \mathrm{y} / & \rightarrow & / \mathrm{n} / \\
\left(\begin{array}{c}
+ \text { nasal } \\
- \text { ant } \\
- \text { cor }
\end{array}\right) & \rightarrow & \left(\begin{array}{c}
+ \text { nasal } \\
+ \text { ant } \\
+ \text { cor }
\end{array}\right)
\end{array}
$$

\subsection{Substitution of Phoneme / $/$ / into /i/}

In the process of absorbing English language into Spanish language, phoneme $/ \mathrm{I} /$ is deleted and turns into /i/, as found in the table below. 
Table 3. Substitution of phoneme / / / into /i/

\begin{tabular}{|c|c|c|}
\hline NO & ENGLISH & SPANISH \\
\hline 1 & bacon [beI-kın] & béicon [bei-kon] \\
\hline 2 & baseball [beIs-bal] & beisbol [beis- $\beta$ ol] \\
\hline 3 & boycott [bor-kat] & boicot [bo-i-kot] \\
\hline 4 & camping [kæmp-ın] & camping [kam-pin] \\
\hline 5 & click [klık] & clic [klik] \\
\hline 6 & comic $[\mathrm{ka}-\mathrm{mIk}]$ & comic [ko-mik] \\
\hline 7 & meeting [mi-rın] & mitin [mi-tin] \\
\hline 8 & nylon [nailpn] & nailon[nai-lon] \\
\hline 9 & parking [pa-kın] & parking[par-kin] \\
\hline 10 & picnic [prk-nık] & picnic[pik-nik] \\
\hline 11 & sandwich [sænd-witf] & sanduche[san-witf] \\
\hline 12 & smoking [sməvkıy] & esmoquin[es-mo-kin] \\
\hline 13 & tennis [tenis] & tenis [te-nis] \\
\hline
\end{tabular}

Below is the phonological rule for this finding.

$$
\left.\left(\begin{array}{c}
\text { /I/ } \\
+ \text { syll } \\
+ \text { high } \\
\text {-back } \\
\text {-tense } \\
\text {-round }
\end{array}\right) \rightarrow \rightarrow \begin{array}{c}
\text { /i/ } \\
+ \text { syll } \\
+ \text { high } \\
- \text { back } \\
+ \text { tense } \\
- \text { round }
\end{array}\right)
$$

\subsection{Substitution of Phoneme /æa/ into /a/}

The short vowel /æ/ in English words is deleted. Then, it turns into /a/ in the borrowing process in Spanish words.

\begin{tabular}{|c|c|c|}
\hline $\mathrm{NO}$ & ENGLISH & SPANISH \\
\hline 1 & basketball [bæs-kit-bal] & básquetbol [bas-ket- $\beta$ ol] \\
\hline 2 & camping [kæmp-In] & camping [kam-pin] \\
\hline 3 & chat [t $\left.\int æ t\right]$ & chat [t]at] \\
\hline 4 & pamphlet [pæm-flıt] & panfleto [pam-fle-to] \\
\hline 5 & panty [pænti] & panti [pan-ti] \\
\hline 6 & sandwich [sænd-wit]] & sanduche [san-witf] \\
\hline 7 & taxi [tæk-si] & taxi [tak-si] \\
\hline
\end{tabular}

Table 4. Substitution of phoneme /æ/ into/a/

The phonological rule is as follows.

$$
\text { læ/ } \quad \rightarrow \quad \text { /a/ }
$$


Ana Puspitasari \& Agus Subiyanto

$$
\left(\begin{array}{c}
+ \text { syll } \\
- \text { high } \\
+ \text { low } \\
\text {-back } \\
\text {-tense } \\
\text {-round }
\end{array}\right) \rightarrow\left(\begin{array}{c}
+ \text { syll } \\
- \text { high } \\
+ \text { low } \\
+ \text { back } \\
- \text { tense } \\
\text {-round }
\end{array}\right)
$$

\subsection{Substitution of Phoneme /a/, /p/, /o/, and / $/$ / into /o/}

In the data below, phoneme $/ \mathrm{a} /, / \mathrm{p} /, / \mathrm{s} /$, and $/ \mho /$ in English words are deleted and they turn into /o/ in Spanish words.

Table 5. Substitution of phoneme /a/,/p/,/o/, and / $/$ into $/ \mathrm{o} /$

\begin{tabular}{|c|c|c|}
\hline NO & ENGLISH & SPANISH \\
\hline 1 & baseball [beIs-bal] & beisbol [beis- $\beta$ ol] \\
\hline 2 & basketball [bæs-kit-bal] & básquetbol [bas-ket- $\beta$ ol] \\
\hline 3 & bowl [boul] & bol [bol] \\
\hline 4 & boycott [bor-kat] & boicot [bo-i-kot] \\
\hline 5 & cocktail [kak-terl] & cóctel [kok-tel] \\
\hline 6 & comic $[\mathrm{ka}-\mathrm{mrk}]$ & comic [ko-mik] \\
\hline 7 & football [futbs:] & fútbol [fut-bol] \\
\hline 8 & goal [goul] & gol [gol] \\
\hline 9 & golf [galf] & golf [golf] \\
\hline 10 & hockey [ha-ki] & hockey [ $\chi 0-k i]$ \\
\hline 11 & nylon [narlpn] & nailon [nai-lon] \\
\hline 12 & post [poust] & post [post] \\
\hline 13 & smoking [smərkın] & esmoquin [es-mo-kin] \\
\hline 14 & snob [snab] & esnob [es-noß] \\
\hline
\end{tabular}

The phonological rule is explained below.

$$
\begin{aligned}
& / \mathrm{a} /, \quad / \mathrm{p} /, \quad / \mathrm{o} /, \quad \mathrm{o} / \mathrm{o} / \mathrm{o}
\end{aligned}
$$

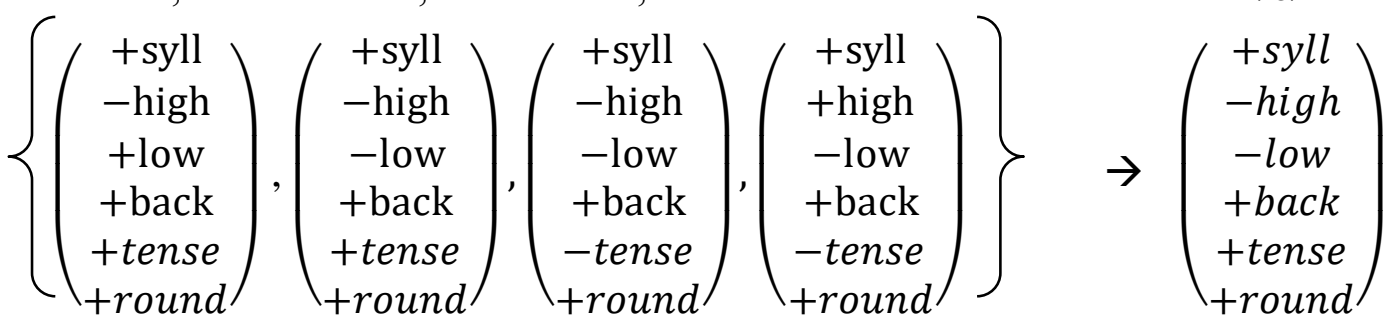




\subsection{Substitution of Phoneme / $/ \mathrm{into} / \mathrm{u} /$}

Phoneme / $/$ does not exist in the phonological system of Spanish language. Thus, when the sound [futbo:], as an example, is absorbed to Spanish language, it is deleted and turns into phoneme $/ \mathrm{u} /$.

Table 6. Substitution of phoneme / $/$ into $/ \mathrm{u} /$

\begin{tabular}{cll}
\hline NO & \multicolumn{1}{c}{ ENGLISH } & \multicolumn{1}{c}{ SPANISH } \\
\hline 1 & football [fotbo:] & fútbol [fut-bol] \\
2 & outlet [aot-lit] & outlet [aut-let] \\
\hline
\end{tabular}

And, this is the phonological rule.

$$
\left.\begin{array}{ccc}
\text { / / } & \rightarrow & / \mathrm{u} / \\
+ \text { syll } \\
+ \text { high } \\
\text {-low } \\
+ \text { back } \\
\text { tense } \\
\text { +round }
\end{array}\right) \rightarrow\left(\begin{array}{c}
+ \text { syll } \\
+ \text { high } \\
- \text { low } \\
+ \text { back } \\
+ \text { tense } \\
+ \text { round }
\end{array}\right)
$$

\section{DISCUSSION}

\subsection{Phonological Differences between English Loanwords in Spanish and their English Words.}

Based on the data in Table 1, the pronunciation of all Spanish words is different from that of English words. Although some data show the same orthographic transcriptions between the Spanish and English words, such as chat, golf, or outlet, they have different phonetic transcriptios. Chat is pronounced as [[t $\left.\int æ t\right]$ in English and [t $\left.\int a t\right]$ in Spanish, golf is pronounced as [galf] in English and [golf] in Spanish, and outlet is pronounced as [aut-let] in English and [aut-lit] in Spanish.

\subsection{Substitution of Consonant Phonemes}

There are changes of phoneme / $\mathfrak{y} /$ in English into / $/$ in Spanish words. Those changes occur in the middle or end of the word. Phoneme $/ \mathrm{y} /$ in the middle position, such as in [gern-stəx] in English is substituted with $/ \mathrm{n} /$ in Spanish [gans-ter]. Or, $/ \mathrm{y} /$ in the final position of the word, such as in [kæmp-In] in English is substituted with $/ \mathrm{n} / \mathrm{in}$ Spanish. Feature [-ant] and [-cor] in $/ \mathfrak{y} /$ change into [+ant] and [+cor] in $/ \mathrm{n} /$, meaning that there is a change of the place where the sound is produced. Phoneme $/ \mathrm{y} /$ is a velar sound, while $/ \mathrm{n} /$ is an alveolar sound. In the phonological system of Spanish language, velar nasal sounds are quite rare. Velar nasal sounds occur only when they are followed by velar consonant $/ \mathrm{k} /, / \mathrm{g} /$, or $/ \mathrm{x} /$ (Kolesnikova, 2017). In the data, no any velar nasal sounds are found since the requirements for nasal velarisation cannot be met. This 
makes the sound of velar nasals in English word is deleted and turns into alveolar nasals $/ \mathrm{n} /$.

\subsection{Substitution of Vowel Phonemes}

\subsubsection{Substitution of Phoneme /// into /i/}

Phoneme /I/ in English changes into phoneme /i/ in Spanish words. It occurs in all positions of the words. The change of phoneme /I/ the initial and ending position of [pık-n $r$ ] into /i/ in [pik-nik] serves as an example for this substitution. Feature [-tense] in phoneme $/ \mathrm{I} /$ changes into [+tense] in phoneme $/ \mathrm{i} /$, denoting that phoneme $/ \mathrm{I} /$ is produced by putting stress on the vowel sound to make a longer sound. Phoneme $/ \mathrm{I} /$ is near-close front unrounded vowel, while /i/ is a close-front unrounded vowel. There is no phoneme $/ \mathrm{I} /$ in the phonological system of Spanish language. Instead, there is only phoneme /i/. This makes it clear why /I/ in English turns into/i/ in Spanish language.

\subsubsection{Substitution of Phoneme /a/ into /a/}

There are changes of phoneme /æ/ in English words into /a/ in Spanish words. The changes occur in the initial position of the words after consonants. Some examples of these changes are when /æ/ in [bæs-kit-bal], [kæmp-In], and [t $\int \mathfrak{~}$ ] turns into [bas-ketßol], [kam-pin], and [t $\left.\int \mathbf{a t}\right]$. Feature [-back] in /æ/ turns into [+back] in /a/, indicating that in the sound change, the highest part of the tongue, which initially placed at the front of the mouth, is slightly moved to the back. Phoneme /æ/ is near-open front unrounded vowel, while /a/ is open front unrounded vowel. Phoneme /æ/ does not exist in Spanish phonology. This explains the reason why it turns into /a/ when the English words are absorbed to Spanish language.

\subsubsection{Substitution of Phoneme /a/, /w/, /s/, and / $/$ / into /o/}

Phoneme /a/, /p/, / /, and / $/$ in English words are deleted in the borrowing process and substituted with /o/. Phoneme /a/ in [ka-mik] turns into /o/ in [ko-mik], phoneme / $/ \mathrm{d} / \mathrm{in}$ [narlpn] turns into /o/ in [nai-lon], phoneme / $/$ in [fotbs:] turns into /o/ in [fut-bol], and phoneme $/ \mho /$ in [poust] turns into /o/ in [post]. Compared to the loanwords in Spanish languages, the features in each English phoneme is almost the same. What makes it different is that feature [+low] in /a/ turns into [-low] in /o/, feature [-tense] in $/ \mathrm{o} /$ and $/ \mathrm{\mho} /$ turns into [+tense] in /o/, and feature [+high] in / / turns into [+high] in /o/. Phoneme $/ \mathrm{a} /$ is a low vowel, then it turns into a mid-vowel $/ \mathrm{o} /$. Phoneme $/ \mathrm{o} /$ and $/ \mathrm{v} /$ are lax vowels; they turn into /o/, which is a tense vowel. Last, phoneme / $/$ is high vowel, produced as the tongue position at a level close to the top of oral cavity, turns into midvowel /o/, which is produced as the tongue moves to a level between high and low vowels. The phonological system in Spanish language does not recognise variations of $/ \mathrm{a} /, / \mathrm{p} /, / \mathrm{s} /$, and $/ \mathrm{\mho} /$. Thus, $/ \mathrm{o} /$ is used as the word absorption process from English to Spanish occurs. 


\subsubsection{Substitution of Phoneme / / / into /u/}

Phoneme $/ \mho /$ in English words turns into $/ \mathrm{u} /$ in Spanish words. Some notable examples are when $/ \mho /$ in [fotbo:] turns into $/ \mathrm{u} /$ in [fut-bol] and $/ \mathrm{v} /$ in [avt-lit] turns into $/ \mathrm{u} /$ in [aut-let]. Feature [-tense] in $/ \mho /$ turns into [+tense] in $/ \mathrm{u} /$. Phoneme $/ \mathrm{v} /$ is a lax vowel; it changes into a tense vowel /u/, implying that there is a change in the efforts of articulation of the vowel and a slightly higher movement of the tongue position. Phoneme $/ \mho /$ does not exist in the phonological system of Spanish language. Thus, phoneme $/ \mho /$ is absorbed to Spanish language, it is deleted and turns into phoneme $/ \mathrm{u} /$.

Based on the result above, the phonological differences between English loanwords in Spanish and English language including the substitution of consonant and vowel phonemes occur because the differences of phonology system of each language. It supports what Aprillianti (2019) and Zen (2016) have said in their studies. Aprillianti (2019), whose study is to investigate the language borrowing in Javanese language says that the sound change occurring in the borrowing process from Arabic, Dutch, and Sanskrit into Javanese is caused by the different phonological system of the languages involved. Zen (2016) also states that phonological system of languages affects the borrowing process of Sansekerta language into Javanese language.

\section{CONCLUSION}

From the analysis of the data above, there are two major categories in the phonological process of English loanwords in Spanish language. Those categories are: (1) the sound change of consonants to consonants, and (2) the sound change of vowels to vowels. In the first category, there is a substitution of phoneme $/ \mathrm{y} /$ into $/ \mathrm{n} /$. In the second category, there is a substitution of phoneme (1) /I/ into /i/; (2) /æa into /a/; (3) /a/, /p/, $/ \mathrm{o} /$ and $/ \mho /$ into $/ \mathrm{o} / ;$ and $(4) / \mho /$ into $/ \mathrm{u} /$. Those differences are caused by the different phonological systems in English as the language, which is borrowed, and Spanish language as the result of the borrowing process.

\section{REFERENCES}

Aikhenvald, A. Y. (2006). Grammars in Contact: A Cross-linguistics Perspective. Oxford: Oxford University Press.

Anam, F. (2017). Ikhfa' "Dwiproses Fonologis dan Kaidah Fonologinya". Tamaddun: Jurnal Kebudayaan dan Sastra Islam. Vol. 17, No. 1, 59-75.

Aprillianti, L. (2019). Distinctive Features Analysis of Foreign Language Borrowing Words in Javanese Language Found in Panjebar Semangat Magazine. Indonesian Journal of EFL and Linguistics Vol. 4 No. 2, 109-120.

Arifiani, E., \& Subianto, A. (2019). Sistem Perubahan Struktur Silabel dan Netralisasi Vokal dalam Bahasa Sasak Dialek Bayan. Jalabahasa, Vol. 15, No. 1, 36-47. 
Ana Puspitasari \& Agus Subiyanto

Association, I. P. (1999). Handbook of the International Phonetic Association: A guide to the use of the International Phonetic Alphabet. Cambridge: Cambridge University Press. Retrieved from https://www.ipachart.com/

Aulia, S. W., \& Nurhayati. (2020). Proses Asimilasi pada Bahasa Sumbawa: Fonologi Generatif. Parafrase, Vol. 20, No. 1, 9-13.

Bojčić, I., \& Plavša, M. B. (2012). Language Borrowing. hrčak.

Coe, N. (1987). in Swam, M. \& Smith, B. Leaner English: A Teacher's Guide to Interference and Other Problems. Cambridge: Cambridge University Press.

Erawati, N. K. (2017). The Interpretation of Sound Segment of Old Javanese: Speech Analyzer and Distinctive Features Analysis. Aksara, 225-238.

Hakim, M. A. (2016). Bahasa Jawa Dialek Brebes: Sebuah Telaah Fonologi Generatif. Jurnal Lingua Idea Vol. 7 No. 2.

Hall, T. A. (2001). Distinctive Feature Theory. Berlin: Mouton de Gruyter.

Hayes, B. (2011). Introductory Phonology. Chihester, West Sussex: Blackwell Publishing.

Huda, R. N., \& Subiyanto, A. (2017). The Phonological Process of Verb Nasalization in Banyumas Dialect of Javanese. Journal on English Language, Culture and Literature Vol. 6 No. 2, 1-10.

Jaya. (2019). Proses Asimilasi Bunyi Konsonan Bahasa Bugis Dialek Sigeri: Kajian Transformasi Generatif. TOLIS Ilmiah: Jurnal Penelitian Vol. 1 No. 1, 43-53.

Kolesnikova, O. (2017). Comparative Analysis of American English and Mexican Spanish Consonants for Computer Assister Pronunciation Training. Revista Signos Vol. 50, No. 94, 195-216.

Lloyd, P. M. (1989). From Latin to Spanish. Philadelphia: American Philosopical Society.

Longman Dictionary of Contemporary English (6th edition). (2014). Harlow: Pearson Education.

Mackenzie, I. (1999-2020). The Linguistics of Spanish. Retrieved from http://www.staff.ncl.ac.uk/i.e.mackenzie/index.html

McMahon, A. (2002). An Introduction to English Phonology. Edinburg: Edinburg University Press.

Moeliono, A. (1988). Tata Bahasa Baku Bahasa Indonesia. Jakarta: Balai Pustaka.

Muslihah. (2018). Proses Penyerapan Bahasa Inggris ke dalam Bahasa Jepang: (Kajian Fonologi Generatfi Transformasional). Izumi, Vol. 7 No, 2, 73-83.

Nafisah, S. (2017). Proses Fonologis dan Pengkaidahan dalam Kajian Fonologi Generatif. DEIKSIS, 70-78.

Nissenberg, G. (2010). Must-Know Spanish: Essential Words for a Successful Vocabulary. USA: McGraw-Hill.

Nykopp, L. (2017, February). The Anglicism About in Informal Written Finnish Discourse. Master's Thesis. University of Helsinki.

Rao, P. S. (2019). The Role of English as a Global Language. RJOE, Vol. 4, No. 1, $65-$ 79. 
Reynaldi, R. G. (2017). Phonological Differences Between Standard Javanese and Banyumas Dialect of Javanese. Compedium: Journal of Cultural, Literary, and Linguistic Studies Vol. 1 No. 1, 15-32.

Salcedo, C. S. (2010). The Phonological System of Spanish. Revista de Linguistica y Lenguas Aplicadas Vol. 10, 195-209.

Schane, S. (1992). Fonologi Generatif. Terjemahan Kentjanawati Gunawan. Jakarta: PT Gelora Aksara Pratama.

Simanjuntak, M. (1990). Teori Distingtif dalam Fonologi Generatif. Jakarta: Gaya Media Pratama.

Sudaryanto. (2015). Metode dan Aneka Teknik Analisis Bahasa. Yogyakarta: Sanata Dharma University Press.

Thomason, S. G. (2001). Language Contact. Edinburg: Edinburg University Press.

Zen, A. L. (2016). Perubahan Fonologis Kosakata Serapan Sansekerta dalam Bahasa Jawa (Analisis Fitur Distingtif dalam Fonologi Transformasi Generatif). Retrieved from Tesis, Pascasarjana. Semarang: Universitas Diponegoro: http://eprints.undip.ac.id/48453/1/ABDUL_LATIF_ZEN.pdf 